\title{
A structural equation model to decipher relationships among water, sanitation, and health in colonias-type unincorporated communities
}

\author{
Lewis Stetson Rowles III ${ }^{1, *}$, Tiffany Whittaker ${ }^{2}$, Peter M. Ward ${ }^{3}$, Isabel Araiza ${ }^{4}$, Mary Jo \\ Kirisits ${ }^{1}$, Desmond F. Lawler ${ }^{1}$, and Navid B. Saleh ${ }^{1, *}$ \\ ${ }^{1}$ Department of Civil, Architectural and Environmental Engineering, University of Texas at \\ Austin, TX, 78712, United States \\ ${ }^{2}$ Educational Psychology Department, University of Texas at Austin, TX, 78712, United States \\ ${ }^{3}$ The Lyndon B. Johnson School of Public Affairs, University of Texas at Austin, TX, 78712, \\ United States \\ ${ }^{4}$ Department of Psychology and Sociology, Texas A\&M University-Corpus Christi, Corpus \\ Christi, TX, 78412, United States
}

Environmental Science \& Technology

* Corresponding authors: Lewis Stetson Rowles III, email: rowles@utexas.edu, phone: (843)

301-1514; Navid B. Saleh, email: navid.saleh@utexas.edu, phone: (512) 471-9175 


\section{SUPPORTING INFORMATION}

\begin{tabular}{|l|l|}
\hline Item & Description \\
\hline Table SI.1 & $\begin{array}{l}\text { Variables and justification of the relationship in the structural equation } \\
\text { model }\end{array}$ \\
\hline Table SI.2a & $\begin{array}{l}\text { Indicator variables with their loading and p-values onto latent variables that } \\
\text { were used the structural equation model }\end{array}$ \\
\hline Table SI.2b & $\begin{array}{l}\text { Indicator variables with their loading and p-values onto latent variables that } \\
\text { were not in used the structural equation model }\end{array}$ \\
\hline Table SI.3 & Standardized total direct and indirect effects \\
\hline Figure SI.1 & $\begin{array}{l}\text { Comparison between Quick Arsenic II and ICP-MS for arsenic } \\
\text { measurements }\end{array}$ \\
\hline Figure SI.2 & Measured water quality \\
\hline Figure SI.3 & Socioeconomic status grouped by county \\
\hline Figure SI.4 & Perceived water quality grouped by county and primary water source \\
\hline Figure SI.5 & Desire to treat water grouped by county \\
\hline Figure SI.6 & $\begin{array}{l}\text { Structural equation model with path values for households that utilize } \\
\text { well/hauled water as their primary source }\end{array}$ \\
\hline Figure SI.7 & $\begin{array}{l}\text { Structural equation model with path values for households that utilize } \\
\text { treated+piped water as their primary source }\end{array}$ \\
\hline Section SI.1 & Survey in English \\
\hline Section SI.2 & Survey in Spanish \\
\hline Section SI.3 & Water sampling and testing \\
\hline Section SI.4 & $\begin{array}{l}\text { Other latent variables probed related to household health, sanitation, and } \\
\text { living in a colonia }\end{array}$ \\
\hline Section SI.5 & $\begin{array}{l}\text { Description of structural equation modeling and code utilized in MPlus and } \\
\text { output from modeling }\end{array}$ \\
\hline
\end{tabular}


Table SI.1: Variables and justification of the relationship in the structural equation model.

\begin{tabular}{|c|c|c|c|}
\hline Independent variable & Dependent variable & Justification & References \\
\hline $\begin{array}{l}\text { Perceived health risks } \\
\text { from current living } \\
\text { conditions }\end{array}$ & Perceived water quality & $\begin{array}{l}\text { Perception of water quality stem from perceived health risks. The greater the risk that the resident feels } \\
\text { from his/her living conditions, the worse he/she will perceive the available water to be. }\end{array}$ & $14,16,17,20$ \\
\hline Safe water practices & Perceived water quality & $\begin{array}{l}\text { Safe water use practices can ensure maintaining water quality. The more care the resident takes in his/her } \\
\text { water use practices, the better he/she will perceive the water to be. }\end{array}$ & 14 \\
\hline $\begin{array}{l}\text { Satisfaction with the } \\
\text { dwelling environment }\end{array}$ & Perceived water quality & $\begin{array}{l}\text { A resident can be satisfied with his/her dwelling environment when the water is perceived to be of good } \\
\text { quality. The more satisfied the resident is with the dwelling, the better will be the perception on water. }\end{array}$ & 15,20 \\
\hline Measured water quality & Perceived water quality & $\begin{array}{l}\text { Generally, residents have an accurate perception of their water quality. The better the measured water } \\
\text { quality, the better will be the resident's perception of his/her water quality. }\end{array}$ & postulated \\
\hline Household health & $\begin{array}{l}\text { Perceived health risks } \\
\text { from current living } \\
\text { conditions }\end{array}$ & $\begin{array}{l}\text { Residents believe that their health is influenced by their living condition. The better the residents' health, } \\
\text { the less risk that they will perceive from their living conditions. }\end{array}$ & 14 \\
\hline $\begin{array}{l}\text { Satisfaction with the } \\
\text { dwelling environment }\end{array}$ & $\begin{array}{l}\text { Perceived health risks } \\
\text { from current living } \\
\text { conditions }\end{array}$ & $\begin{array}{l}\text { Perceived health risk is influenced by the satisfaction with the dwelling environment. The more satisfied } \\
\text { the resident is with his/her dwelling environment, the less risk will be perceived. }\end{array}$ & 14 \\
\hline $\begin{array}{l}\text { Extent of sanitation and } \\
\text { waste management }\end{array}$ & Household health & $\begin{array}{l}\text { The status of sanitation and waste management can influence household health. Unimproved sanitation } \\
\text { and waste management services can degrade water quality, leading to possible health issues. }\end{array}$ & 23 \\
\hline Measured water quality & Household health & Measured water quality can influence household health. Poor water quality can also lead to health issues. & postulated \\
\hline Safe water use practices & Household health & $\begin{array}{l}\text { Safe water use practices can influence household health. If a household does not follow safe water use } \\
\text { practices, their health can suffer. }\end{array}$ & 23 \\
\hline Socio-economic status & Household health & $\begin{array}{l}\text { Socio-economic status can be a predictor for household health. Higher socio-economic status allows } \\
\text { households to afford better health services. }\end{array}$ & 23 \\
\hline $\begin{array}{l}\text { Extent of sanitation and } \\
\text { waste management }\end{array}$ & Measured water quality & $\begin{array}{l}\text { The status of sanitation and waste management can influence measured water quality. Unimproved } \\
\text { sanitation and waste management services can degrade water quality, leading to possible health issues. }\end{array}$ & postulated \\
\hline Safe water use practices & Measured water quality & $\begin{array}{l}\text { Safe water use practices can influence measured water quality. If a household does not follow safe water } \\
\text { use practices, their water can become contaminated. }\end{array}$ & postulated \\
\hline Education level & Safe water use practices & $\begin{array}{l}\text { Education level increases knowledge on safe water use practices. Households with higher education } \\
\text { understand the impact their interaction with water can have on its quality. }\end{array}$ & 23 \\
\hline Socio-economic status & Safe water use practices & $\begin{array}{l}\text { Socio-economic status increases the ability to purchase necessary containers and to follow safe water use } \\
\text { practices. Higher socio-economic status households have greater ability to purchase containers to safely } \\
\text { manage their water. }\end{array}$ & 23 \\
\hline Education level & Socio-economic status & $\begin{array}{l}\text { Education level generally increases socio-economic status. Higher education level gives residents } \\
\text { opportunities to have higher paying jobs. }\end{array}$ & 18 \\
\hline Perceived water quality & Desire to treat water & $\begin{array}{l}\text { Perception of water quality influences desire to treat water. If a resident believes that his/her water is of } \\
\text { good quality, he/she will be less likely to have a desire to treat it. }\end{array}$ & postulated \\
\hline $\begin{array}{l}\text { Perceived health risk from } \\
\text { current living conditions }\end{array}$ & Desire to treat water & $\begin{array}{l}\text { Perception of health risks influences desire to treat water. If a resident believes he/she has low health } \\
\text { risks from water, he/she will be less likely to have a desire to treat water. }\end{array}$ & postulated \\
\hline Household health & Desire to treat water & $\begin{array}{l}\text { Household health influences desire to treat water. If a resident has better overall health, he/she will be } \\
\text { less likely to have a desire to treat water. }\end{array}$ & postulated \\
\hline Socio-economic status & $\begin{array}{l}\text { Satisfaction with the } \\
\text { dwelling environment }\end{array}$ & $\begin{array}{l}\text { Higher socio-economic status allows residents to make improvements in their dwelling environment; } \\
\text { thus, they can increase satisfaction with their dwelling environment. }\end{array}$ & postulated \\
\hline $\begin{array}{l}\text { Security of water quality } \\
\text { and quantity }\end{array}$ & $\begin{array}{l}\text { Satisfaction with the } \\
\text { dwelling environment }\end{array}$ & $\begin{array}{l}\text { Higher security of water quality and quantity makes the resident more satisfied with their dwelling } \\
\text { environment. }\end{array}$ & postulated \\
\hline Socio-economic status & $\begin{array}{l}\text { Security of water quality } \\
\text { and quantity }\end{array}$ & $\begin{array}{l}\text { Socio-economic status increases the ability to purchase items that increase water quality and quantity. } \\
\text { Higher socio-economic status households have higher security of water quality and quantity. }\end{array}$ & postulated \\
\hline
\end{tabular}


Table SI.2a: Indicator variables are shown with their relative latent variables and calculated standardized loading and $\mathrm{p}$-value that were included in the structural equation model. Variables were included in the model is they had at least three measures/questions with loadings $>0.4$ and p-values $<0.05$.

\begin{tabular}{|c|c|c|c|}
\hline measure/question & latent variable & loading & p-value \\
\hline $\begin{array}{l}\text { I believe the quality of my tap water needs } \\
\text { improvement.* }\end{array}$ & Perceived water quality & 0.847 & $<0.001$ \\
\hline I am happy with the taste of my tap water. & Perceived water quality & 0.791 & $<0.001$ \\
\hline My tap water is usually of high quality. & Perceived water quality & 0.761 & $<0.001$ \\
\hline $\begin{array}{l}\text { There are many health risks associated with drinking } \\
\text { tap water in my home. }\end{array}$ & $\begin{array}{l}\text { Perceived health risk from } \\
\text { current living conditions }\end{array}$ & 0.816 & $<0.001$ \\
\hline My tap water will not harm anybody.* & $\begin{array}{l}\text { Perceived health risk from } \\
\text { current living conditions }\end{array}$ & 0.822 & $<0.001$ \\
\hline $\begin{array}{l}\text { I believe there is a possibility of becoming ill from } \\
\text { drinking water straight from my tap. }\end{array}$ & $\begin{array}{l}\text { Perceived health risk from } \\
\text { current living conditions }\end{array}$ & 0.897 & $<0.001$ \\
\hline $\begin{array}{l}\text { There are so many chemicals and additives in my tap } \\
\text { water that it must be unhealthy. }\end{array}$ & $\begin{array}{l}\text { Perceived health risk from } \\
\text { current living conditions }\end{array}$ & 0.818 & $<0.001$ \\
\hline $\begin{array}{l}\text { There are many health risks associated with air quality } \\
\text { in my home. }\end{array}$ & $\begin{array}{l}\text { Perceived health risk from } \\
\text { current living conditions }\end{array}$ & 0.465 & 0.012 \\
\hline $\begin{array}{l}\text { I believe there is a possibility of becoming ill from the } \\
\text { air in my home. }\end{array}$ & $\begin{array}{l}\text { Perceived health risk from } \\
\text { current living conditions }\end{array}$ & 0.478 & 0.002 \\
\hline $\begin{array}{l}\text { In general, I would be happy living in this area for the } \\
\text { next } 15 \text { years. }\end{array}$ & $\begin{array}{l}\text { Satisfaction with the } \\
\text { dwelling environment }\end{array}$ & 0.686 & $<0.001$ \\
\hline I feel safe living in this colonia. ${ }^{\#}$ & $\begin{array}{l}\text { Satisfaction with the } \\
\text { dwelling environment }\end{array}$ & 0.524 & 0.005 \\
\hline $\begin{array}{l}\text { If I had the opportunity, I would rather live in another } \\
\text { area.* }\end{array}$ & $\begin{array}{l}\text { Satisfaction with the } \\
\text { dwelling environment }\end{array}$ & 0.853 & $<0.001$ \\
\hline $\begin{array}{l}\text { I would feel safe leaving this colonia to move to a new } \\
\text { town.* }\end{array}$ & $\begin{array}{l}\text { Satisfaction with the } \\
\text { dwelling environment }\end{array}$ & 0.784 & $<0.001$ \\
\hline $\begin{array}{l}\text { I would be happy if my children moved out of this } \\
\text { colonia.* }\end{array}$ & $\begin{array}{l}\text { Satisfaction with the } \\
\text { dwelling environment }\end{array}$ & 0.494 & 0.018 \\
\hline $\begin{array}{l}\text { From now, how long are you planning to live in this } \\
\text { colonia? (in years) }\end{array}$ & $\begin{array}{l}\text { Satisfaction with the } \\
\text { dwelling environment }\end{array}$ & 0.481 & $<0.001$ \\
\hline Do you think your children will live in this colonia?* & $\begin{array}{l}\text { Satisfaction with the } \\
\text { dwelling environment }\end{array}$ & 0.561 & $<0.001$ \\
\hline Frequency of adults getting diarrhea. $^{+}$ & Household health & 0.970 & $<0.001$ \\
\hline Frequency of elderly getting diarrhea. ${ }^{+}$ & Household health & 0.890 & $<0.001$ \\
\hline Frequency of children getting diarrhea. ${ }^{+}$ & Household health & 0.801 & $<0.001$ \\
\hline Frequency of adults getting respiratory sickness. ${ }^{+}$ & Household health & 0.489 & $<0.001$ \\
\hline Frequency of elderly getting respiratory sickness. ${ }^{+}$ & Household health & 0.420 & 0.003 \\
\hline Frequency of children getting respiratory sickness. ${ }^{+}$ & Household health & 0.498 & 0.021 \\
\hline
\end{tabular}

$*=($ reverse coded $) ;{ }^{+}=($coded $1=$ weekly to $5=$ never $) ;{ }^{*}=($ no $=0$, yes $=1)$; Unless otherwise noted, observed variables are to be measured using 5 point Likert scale where $1=$ strongly disagree, $5=$ strongly agree 
Table SI.2b: Indicator variables are shown with their relative latent variables and calculated standardized loading and p-value that were not in used the structural equation model, i.e., loading $<0.4$ and/or p-value $>0.05$.

\begin{tabular}{|c|c|c|c|}
\hline measure/question & latent variable & loading & p-value \\
\hline I am happy with the color of my tap water. & Perceived water quality & 0.220 & 0.192 \\
\hline I am happy with the odor of my tap water. & Perceived water quality & 0.359 & 0.025 \\
\hline The air in my home will not harm anybody.* & $\begin{array}{l}\text { Perceived health risk from } \\
\text { current living conditions }\end{array}$ & 0.245 & 0.048 \\
\hline I am willing to leave this colonia. & $\begin{array}{l}\text { Satisfaction with the } \\
\text { dwelling environment }\end{array}$ & -0.115 & 0.584 \\
\hline How long have you been in the US? (in years) & $\begin{array}{l}\text { Satisfaction with the } \\
\text { dwelling environment }\end{array}$ & -0.096 & 0.427 \\
\hline How long have you lived in this colonia? (in years) & $\begin{array}{l}\text { Satisfaction with the } \\
\text { dwelling environment }\end{array}$ & 0.094 & $<0.001$ \\
\hline $\begin{array}{l}\text { I am happy with the amount of water I have available } \\
\text { to use from the tap }\end{array}$ & $\begin{array}{l}\text { Security of water quality } \\
\text { and quantity }\end{array}$ & 0.888 & 0.001 \\
\hline $\begin{array}{l}\text { I would like to have better quality water piped to my } \\
\text { home. }\end{array}$ & $\begin{array}{l}\text { Security of water quality } \\
\text { and quantity }\end{array}$ & -0.039 & 0.845 \\
\hline $\begin{array}{l}\text { The quality of my tap water has gotten better since I } \\
\text { moved to this colonia. }\end{array}$ & $\begin{array}{l}\text { Security of water quality } \\
\text { and quantity }\end{array}$ & -0.348 & 0.349 \\
\hline $\begin{array}{l}\text { Whenever I turn on my tap, there is a plentiful supply } \\
\text { of water. }\end{array}$ & $\begin{array}{l}\text { Security of water quality } \\
\text { and quantity }\end{array}$ & 0.999 & $<0.001$ \\
\hline $\begin{array}{l}\text { The number of water containers I have meets my } \\
\text { family's needs }\end{array}$ & $\begin{array}{l}\text { Security of water quality } \\
\text { and quantity }\end{array}$ & 0.999 & $<0.001$ \\
\hline $\begin{array}{l}\text { Highest education level of person currently living in } \\
\text { house. (coded } 1=\text { some primary to } 6=\text { completed } \\
\text { university) }\end{array}$ & Education level & 0.180 & 0.486 \\
\hline Percent of people who can speak English & Education level & 0.940 & $<0.001$ \\
\hline Percent of people who can read and write English & Education level & 0.935 & $<0.001$ \\
\hline Monthly income (coded $1=<\$ 250$ to $5=>\$ 1500$ ) & Socio-economic status & 0.075 & 0.416 \\
\hline Own home ${ }^{\#}$ & Socio-economic status & 0.638 & 0.029 \\
\hline Have a deed ${ }^{\#}$ & Socio-economic status & 0.736 & $<0.001$ \\
\hline Own land ${ }^{\#}$ & Socio-economic status & 0.494 & $<0.001$ \\
\hline Number of bedrooms & Socio-economic status & 0.699 & $<0.001$ \\
\hline Number of bathrooms & Socio-economic status & 0.421 & 0.015 \\
\hline Cover all containers ${ }^{\#}$ & Safe water use practices & 0.009 & 0.696 \\
\hline $\begin{array}{l}\text { Remove water in safe manor from all containers (pour } \\
\text { directly }=1 \text {, scoop with handle }=2 \text {, scoop without } \\
\text { handle }=3 \text {, spigot }=4 \text {, other }=5 ; 3 \text { and } 5 \text { classified as } \\
\text { unsafe) }\end{array}$ & Safe water use practices & 0.057 & 0.996 \\
\hline
\end{tabular}


Table SI.3: Standardized total direct and indirect effects between measured water quality (MWQ), household health (HH), perceived health risk from living conditions (PHR), satisfaction with the dwelling environment (SDE), perceived water quality (PWQ), and desire to treat water (DTW).

\begin{tabular}{lcc}
\hline Path & Direct effect & Indirect effect \\
\hline $\mathrm{MWQ} \rightarrow \mathrm{HH}$ & $0.169^{*}$ & \\
$\mathrm{MWQ} \rightarrow \mathrm{HH} \rightarrow \mathrm{PHR}$ & & $0.027^{*}$ \\
$\mathrm{MWQ} \rightarrow \mathrm{HH} \rightarrow \mathrm{PHR} \rightarrow \mathrm{DTW}$ & & -0.006 \\
$\mathrm{MWQ} \rightarrow \mathrm{PWQ}$ & 0.155 & \\
$\mathrm{MWQ} \rightarrow \mathrm{HH} \rightarrow \mathrm{PHR} \rightarrow \mathrm{PWQ}$ & & $0.018^{*}$ \\
$\mathrm{HH} \rightarrow \mathrm{PHR}$ & $-0.187^{*}$ & \\
$\mathrm{HH} \rightarrow \mathrm{PHR} \rightarrow \mathrm{DTW}$ & & -0.044 \\
$\mathrm{HH} \rightarrow \mathrm{PHR} \rightarrow \mathrm{PWQ}$ & & $0.131^{*}$ \\
$\mathrm{HH} \rightarrow \mathrm{DTW}$ & -0.120 & \\
$\mathrm{SDE} \rightarrow \mathrm{PHR}$ & $-0.894^{* * *}$ & \\
$\mathrm{SDE} \rightarrow \mathrm{PHR} \rightarrow \mathrm{DTW}$ & & -0.025 \\
$\mathrm{SDE} \rightarrow \mathrm{PHR} \rightarrow \mathrm{PWQ}$ & & 0.074 \\
$\mathrm{PHR} \rightarrow \mathrm{DTW}$ & 0.258 & \\
$\mathrm{PHR} \rightarrow \mathrm{PWQ}$ & $-0.640^{* * *}$ & \\
$\mathrm{PWQ} \rightarrow \mathrm{DTW}$ & 0.098 & \\
\hline Note: $* \mathrm{p}<0.05, * * \mathrm{p}<0.01, * * * \mathrm{p}<0.001$ &
\end{tabular}




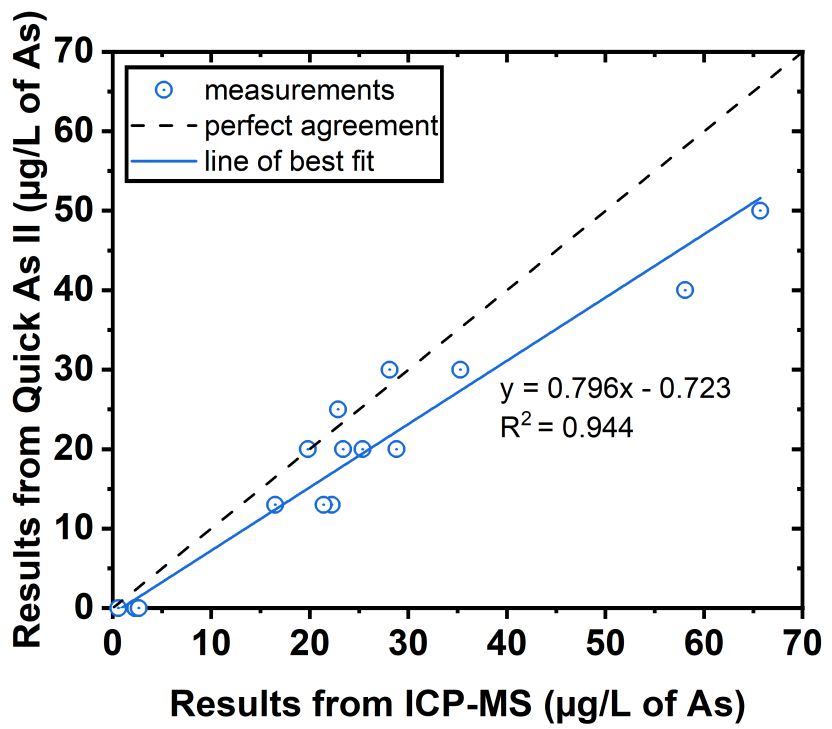

Figure SI.1: Comparison between Quick Arsenic II and ICP-MS for arsenic measurements. 

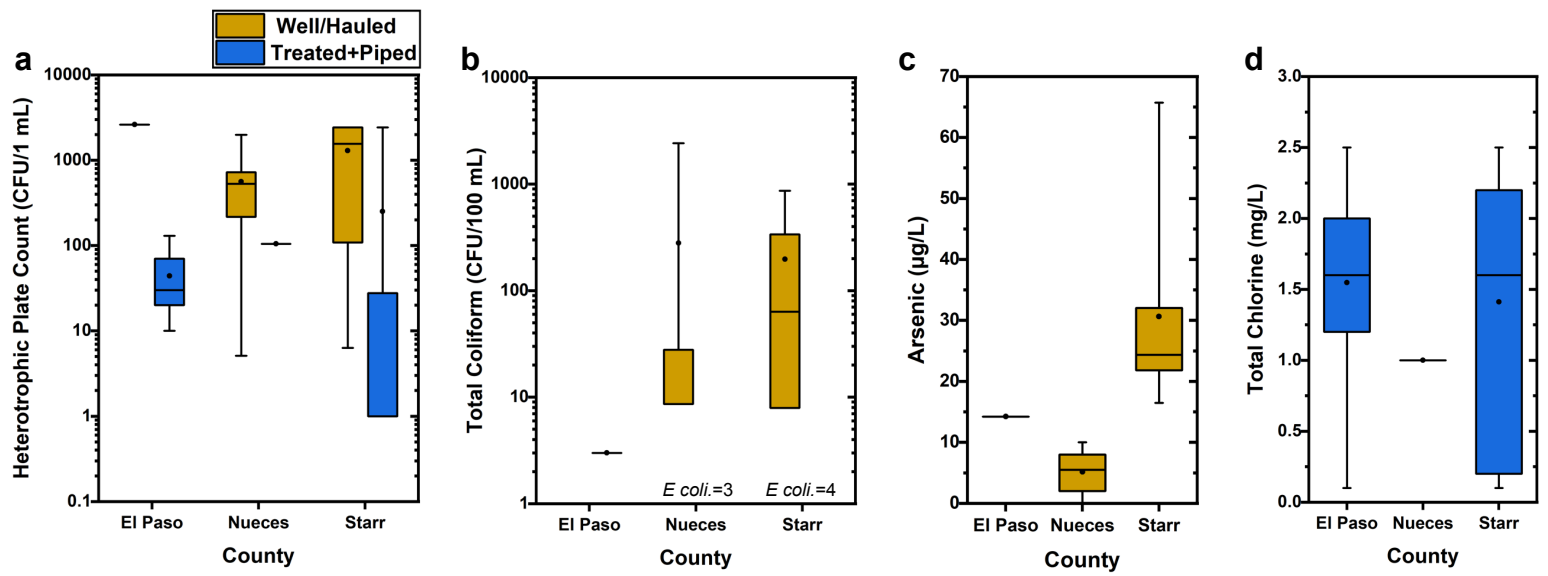

Figure SI.2: Measured water quality shown by (a) heterotrophic plate count, (b) total coliforms with number of samples positive for $E$. coli, (c) arsenic concentration, and (d) total chlorine. In the box plots, the whiskers represent minimum and maximum, the box shows the interquartile range, the line across the box is the median, and the point within the box represents the mean. 

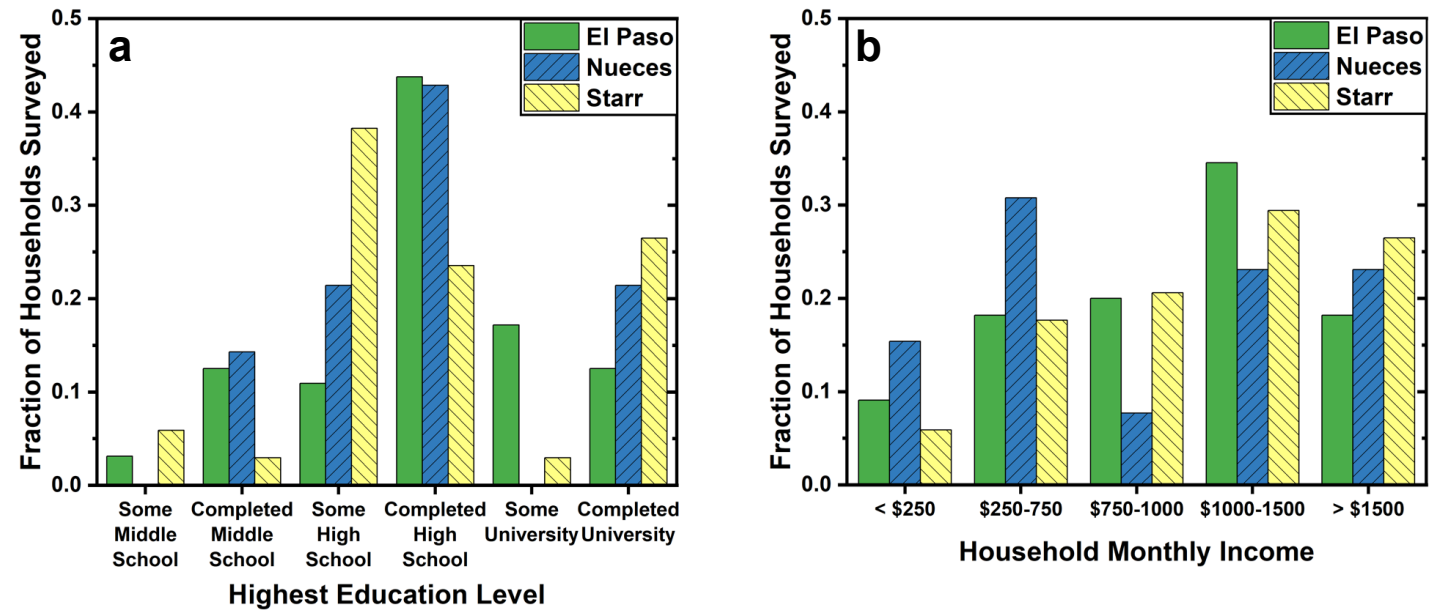

Figure SI.3: Socioeconomic status of surveyed colonias residents shown by (a) educational level and (b) household monthly income. 


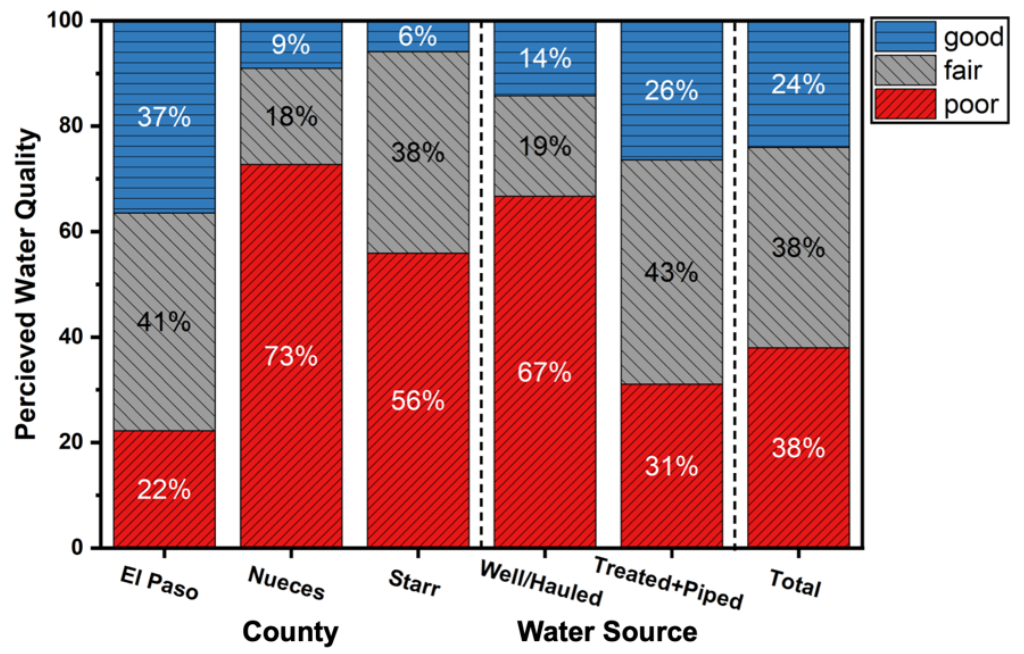

Figure SI.4: Perceived water quality grouped by county and primary water source. 

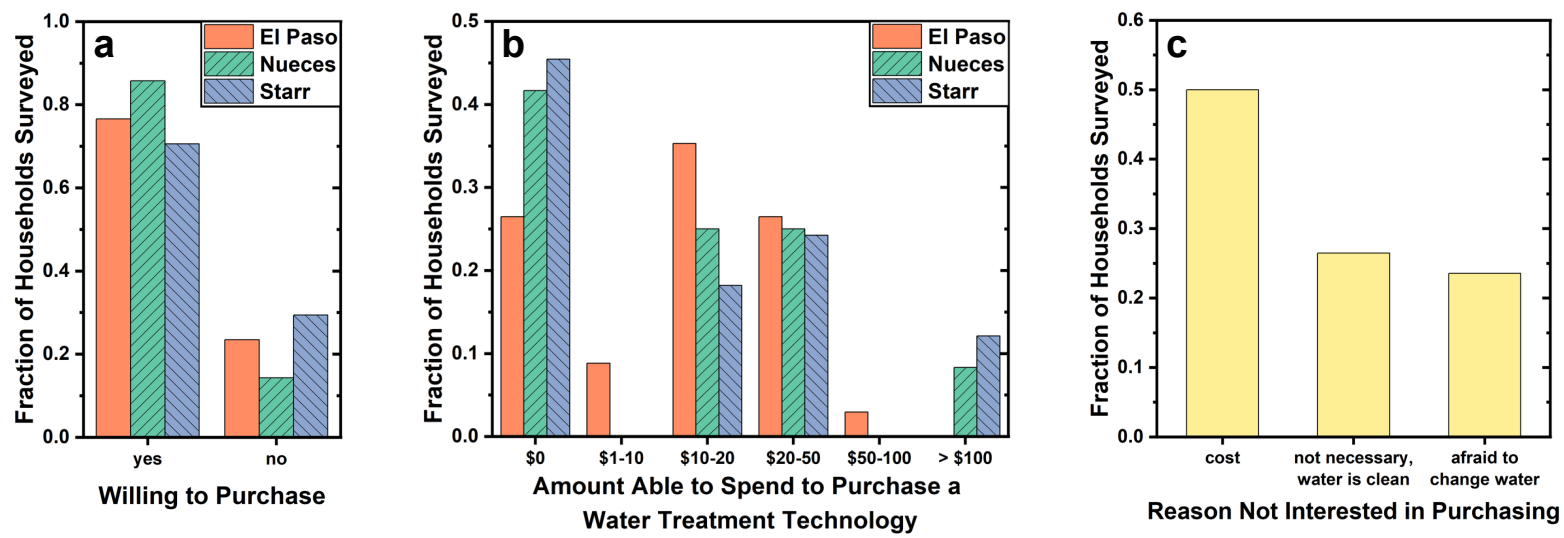

Figure SI.5: Desire to treat water shown by (a) willingness to purchase a point-of-use water treatment technology, (b) amount able to spend, and (b) reason not interested in purchasing. 


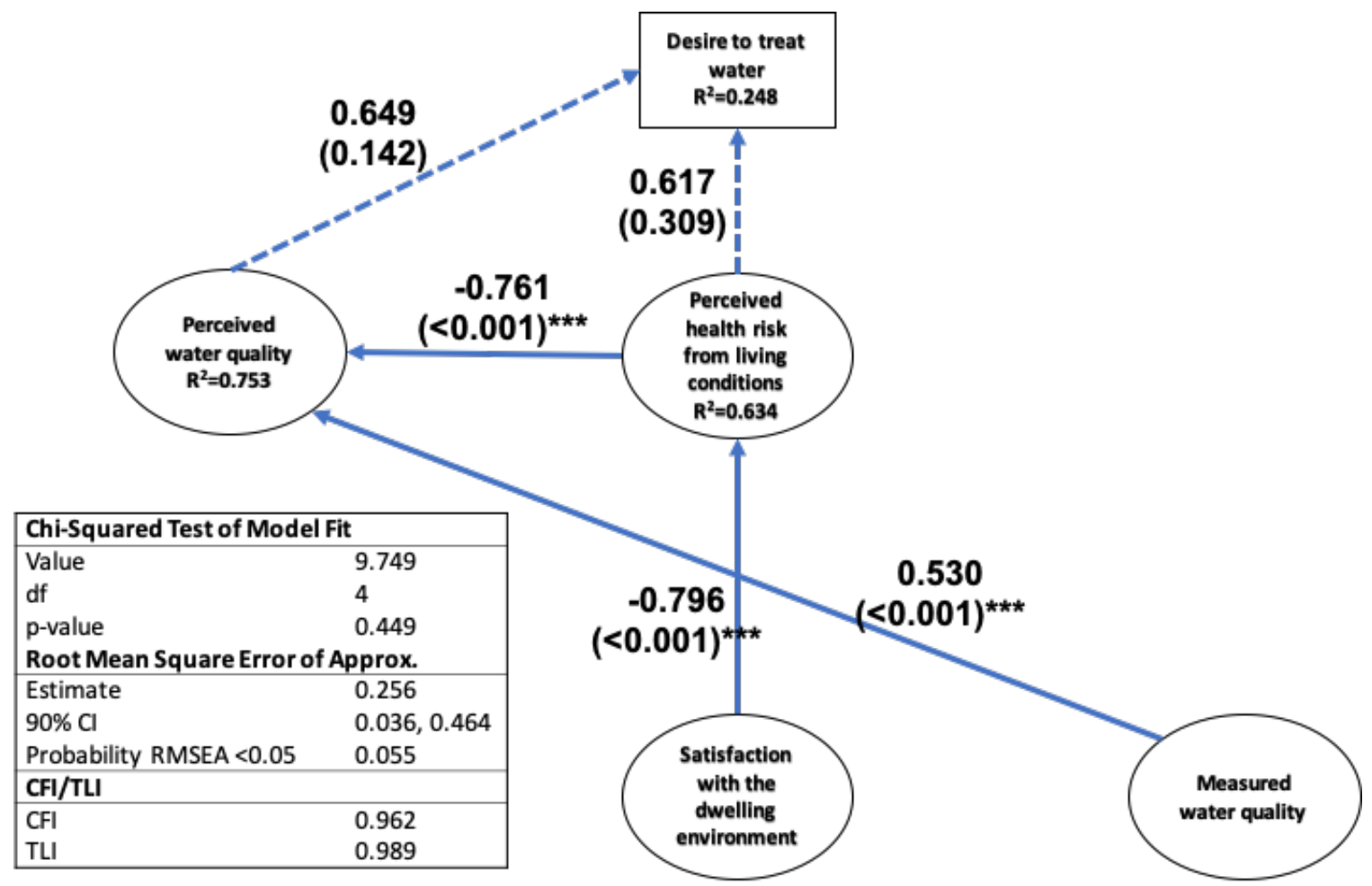

Figure SI.6: Structural equation model with path values for households that utilize well/hauled water as their primary source. The top number on each path is the standardized path value, and the bottom number is the p-value. Paths with significant p-value of less than 0.05 are shown as solid. Dashed paths are non-significant. Significance is also noted as: ${ }^{*} p<0.05, * * p<0.01$, and $* * * \mathrm{p}<0.001$. The model fit information for the structural model generated by Mplus is displayed in the insert table. The code and output can be found the SI. 


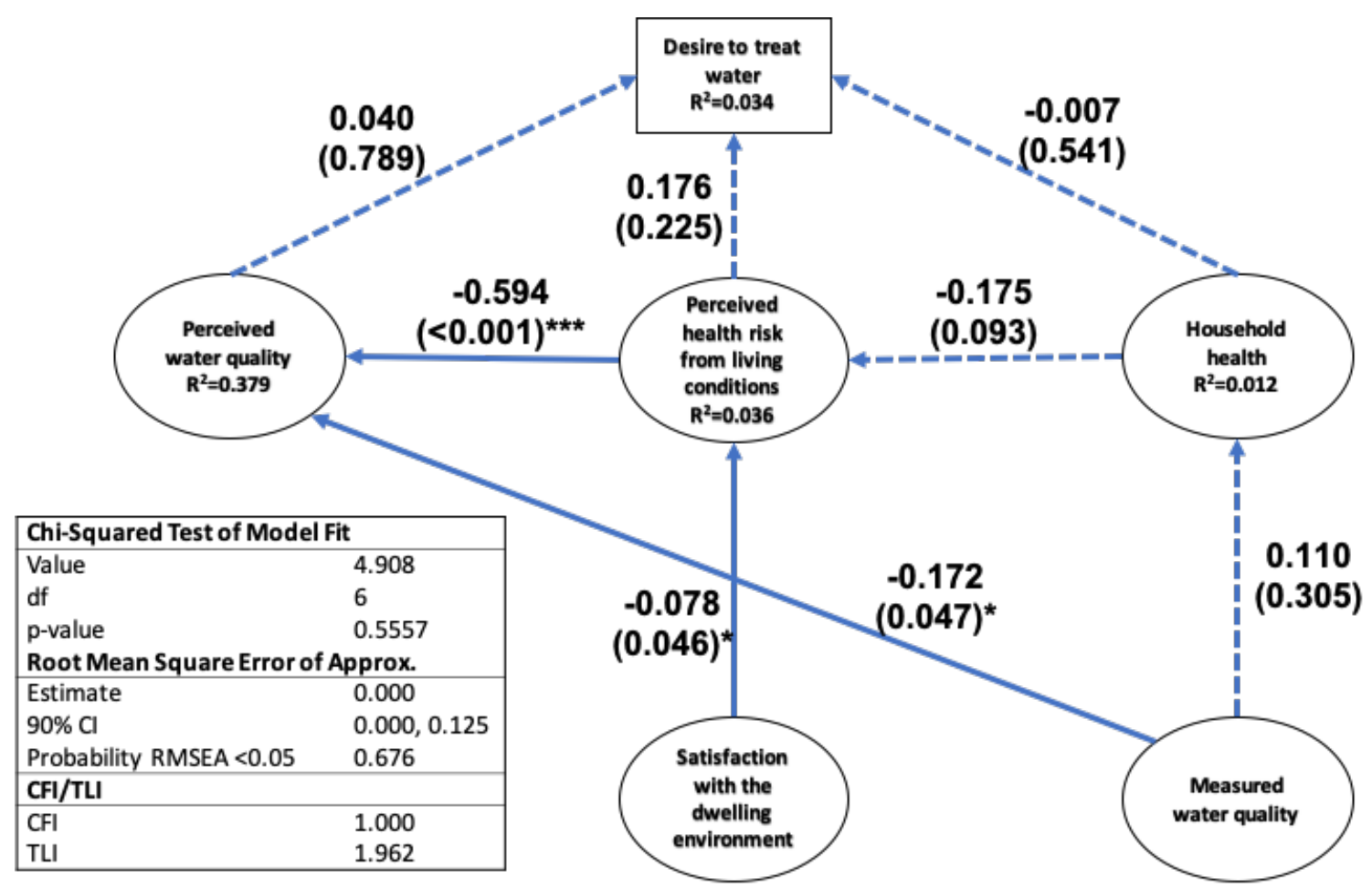

Figure SI.7: Structural equation model with path values for households that utilize treated+piped water as their primary source. The top number on each path is the standardized path value, and the bottom number is the p-value. Paths with significant $p$-value of less than 0.05 are shown as solid. Dashed paths are non-significant. Significance is also noted as: $* p<0.05, * * p<0.01$, and $* * * p<0.001$. The model fit information for the structural model generated by Mplus is displayed in the insert table. The code and output can be found the SI. 
Section SI.1: Survey in English

\section{Colonias: Household Baseline Survey}

\subsection{Introduction:}

-Hello my name is and I am a (professor/student) from

-We have permission from ___ we are not associated with any government agency. We are students learning about water in the area.

-May we speak to the head of household. (if not available, ask for adult over the age of 18)

- We are conducting a household survey on water and sanitation in Colonias. We would like to talk to you for about 15 minutes. Participation is voluntary: you may decline to answer any or all the questions, and you may end the questionnaire early if you wish. All the information will be kept confidential. Do you understand? Do you have any questions?

1.1 Will you be willing to participate? Yes No

(if no, thank and leave)

2.0 Interview background (by surveyor)

\begin{tabular}{|l|c|}
\hline Survey number $(1,2,3 \ldots)$ & \\
\hline Name of surveyor & \\
\hline Community & $/$ \\
\hline Date & $/$ \\
\hline Start time - End time (duration) & \\
\hline GPS coordinates (N/S, E/W) & Trailer or foundation \\
\hline Type of home & mins) \\
\hline
\end{tabular}

\subsection{Household information}

3.1 Age:

Gender:

3.2 What is the highest education level of any person currently living in your home?

Some primary Completed primary Some secondary

Completed secondary Some university Completed university

3.3 Number of adults (age 18-65) in household (Including you)

3.4 Number of elderly (over 65) in household

3.5 Number of children $(<18)$ in household

3.6 Ages of children:

3.7 What is your occupation?

How many people can read and write in English in your home?

$3.8 \mathrm{Read} / \mathrm{write}$

3.9 Speak

3.10 What is your monthly income? (circle one)

Less than $\$ 250 \quad \$ 250-750 \quad \$ 750-1000 \quad \$ 1000-1500$

over $\$ 1500$ per month 
Do you have __ ? (check if they have)

\begin{tabular}{|c|c|}
\hline 3.11 & Electricity \\
\hline 3.12 & Microwave \\
\hline 3.13 & Cell phone \\
\hline 3.14 & Smart phone \\
\hline 3.15 & Internet \\
\hline 3.16 & $\begin{array}{l}\text { Running tap water (potable or } \\
\text { non-potable) }\end{array}$ \\
\hline 3.17 & Sewer line \\
\hline 3.18 & Septic tank \\
\hline 3.19 & Garbage pick-up \\
\hline 3.20 & Shower \\
\hline
\end{tabular}

3.21 Do you rent or own your home? (circle one) Rent Own

3.22 If own, do you have a deed? (circle one) Yes No

3.23 Do you own the land? (circle one) Yes No

3.24 How many bedrooms do you have in your home?

3.25 How many bathrooms do you have in your home?

\subsection{Household Hygiene}

Do you always wash your hands___ ? (check yes/no for each)

\begin{tabular}{|l|l|l|l|}
\hline & & Yes & No \\
\hline 4.1 & After the toilet & & \\
\hline 4.2 & Before eating & & \\
\hline 4.3 & Before cooking & & \\
\hline 4.4 & Other & & \\
\hline
\end{tabular}

4.5 Do you use always soap when washing your hands? $\quad$ Yes No

\subsection{Health}

Complete the following statements after first verbally explain diarrhea as loose, watery stools (bowel movements):

5.1 Adults (18-65) in the household get diarrhea

Very often (weekly) Often (monthly) Sometimes (several times per year) Rarely

Never

5.2 Elderly ( $>65)$ in the household get diarrhea 
Very often (weekly) Often (monthly) Sometimes (several times per year) Rarely Never

5.3 Children in the household get diarrhea

Very often (weekly) Often (monthly) Sometimes (several times per year) Rarely Never

5.4 Do you think is a cause of the diarrhea? (read all options and check all that apply)

\begin{tabular}{|l|l|}
\hline Dirty water & \\
\hline Dirty food & \\
\hline Flies/insects & \\
\hline Poor hygiene/environment & \\
\hline Other & \\
\hline Unsure & \\
\hline
\end{tabular}

5.5 Do you treat your diarrhea symptoms? Yes No

5.6 Adults (18-65) in the household get respiratory sicknesses (cough and mucus)

Very often (weekly) Often (monthly) Sometimes (several times per year) Rarely Never

5.7 Elderly $(>65)$ in the household get respiratory sicknesses (cough and mucus)

Very often (weekly) Often (monthly) Sometimes (several times per year) Rarely Never

5.8 Children in the household get respiratory sicknesses (cough and mucus)

Very often (weekly) Often (monthly) Sometimes (several times per year) Rarely

Never

5.9 What do you think is the main cause of respiratory sicknesses?

(Write answer)

5.10 Do you treat your respiratory sicknesses symptoms? Yes No

5.11-5.15 Do you ?

\begin{tabular}{|l|l|}
\hline Use a humidifier & \\
\hline Take showers & \\
\hline Use a shower at work & \\
\hline Work in/near a building with a cooling tower & \\
\hline Smoke & \\
\hline
\end{tabular}

6.0 Safe Water Use Practices 6.1 Source collection: 
Where do you get your drinking water (note as D)? Water for other uses (note as $\mathbf{U}$ ) (mark if D and $U$ )

\begin{tabular}{|l|l|l|l|}
\hline Source & Always & Sometimes & Estimated cost per month (\$) \\
\hline Household tap & & & \\
\hline Tanker truck delivery & & & \\
\hline Water vending machine filling station & & & \\
\hline Bottled water & & & \\
\hline Well & & & \\
\hline Other & & & \\
\hline
\end{tabular}

(If they purchase drinking water other than from the tap i.e., bottled and vending)

Why do you purchase drinking water other than from the tap? (check one)

\begin{tabular}{|l|l|l|}
\hline Reason & Check if applies & comments \\
\hline $\begin{array}{l}\text { You were told the piped water is } \\
\text { unsafe (list who told in comments) }\end{array}$ & & \\
\hline $\begin{array}{l}\text { It is your belief to buy separate } \\
\text { drinking water }\end{array}$ & & \\
\hline $\begin{array}{l}\text { You have always drunk purchased } \\
\text { water only }\end{array}$ & & \\
\hline Other (specify) & & \\
\hline
\end{tabular}

6.3 Do you use your tap water for

? (check all that apply)

\begin{tabular}{|l|l|}
\hline Drinking & \\
\hline Washing hands & \\
\hline Washing dishes & \\
\hline Washing clothes & \\
\hline Cooking & \\
\hline Taking bath/shower & \\
\hline
\end{tabular}

6.4 Is water always available from these sources? If not, please explain discontinuity.

\section{Water Storage:}

6.5 Where do you store your water in the household? (circle all that apply)

\begin{tabular}{|l|l|l|l|}
\hline & Number & Approximate size (L) & Age of container (months) \\
\hline Plastic water jug & & & \\
\hline Ceramic vessels & & & \\
\hline Metal buckets & & & \\
\hline Plastic buckets & & & \\
\hline
\end{tabular}




\begin{tabular}{|l|l|l|l|}
\hline Jerry can & & & \\
\hline Small pans & & & \\
\hline Cooking pots & & & \\
\hline Other (specify) & & & \\
\hline
\end{tabular}

6.7 Are all of your storage vessels always covered? Yes

No

6.8 How do you take water from the storage containers? (check as many that apply)

\begin{tabular}{|l|l|}
\hline Pour directly & \\
\hline Draw with cup or scoop with handle & \\
\hline Draw with cup or scoop without handle & \\
\hline Spigot on container & \\
\hline Other (specify) & \\
\hline
\end{tabular}

\subsection{Perception of water quality}

Rate the following for your tap (non-bottled) water (1-disagree, 5-agree)

7.1 I believe the quality of my tap water needs improvement.

7.2 I am happy with the taste of my tap water.

7.3 I am happy with the color of my tap water.

7.4 I am happy with the odor of my tap water.

7.5 My tap water is usually of high quality.

8.0 Perceived health risks from current living conditions.

Rate the following for your tap (non-bottled) water (1-disagree, 5-agree)

8.1 There are many health risks associated with drinking tap water in my home.

8.2 My tap water will not harm anybody.

8.3 I believe there is a possibility of becoming ill from drinking water straight from my tap.

8.4 There are so many chemicals and additives in my tap water that it must be unhealthy.

8.5 There are many health risks associated with air quality in my home.

8.6 The air in my home will not harm anybody.

8.7 I believe there is a possibility of becoming ill from the air in my home.

\subsection{Satisfaction with the dwelling environment}

\section{Rate the following (1-disagree, 5-agree)}

9.1 In general, I would be happy living in this area for the next 15 years.

9.2 I feel safe living in this colonia.

9.3 If I had the opportunity, I would rather live in another area.

9.4 I would feel safe leaving this colonia to move to a new town.

9.5 I would be happy if my children moved out of this colonia.

9.6 I am willing to leave this colonia.

9.7 How long have you been in the US? (in years)

9.8 How long have you lived in this colonia? (in years)

9.9 From now, how long are you planning to live in this colonia? (in years) 
9.10 Do you think your children will live in this colonia? (circle one) Yes No

9.11 Would you be comfortable if your grown child moved $>200$ miles away for school/work? Yes No

\subsection{Security of Water Quality and Quantity}

Rate the following (1-disagree, 5-agree)

$10.1 \mathrm{I}$ am happy with the amount of water I have available to use from the tap.

10.2 I would like to have better quality water piped to my home.

10.3 The quality of my tap water has gotten better since I moved to this colonia.

10.4 Whenever I turn on my tap, there is a plentiful supply of water.

10.5 The number of water containers I have meets my family's needs.

\subsection{Water Treatment}

11.1 Are you treating your water from the tap?

Yes No

(If yes) What type of treatment and what is the cost?

11.2 Device/method:

11.3 Cost to purchase:

11.4 Operation/maintenance cost:

11.5 How often do you complete maintenance on this device? (circle one)

yearly monthly weekly never

Preparedness to use household treatment (If they DON'T have household water treatment):

11.6 Would you like to treat your water before drinking? Yes No

11.7 If not, why not? (check all that apply)

\begin{tabular}{|l|l|}
\hline Cost & \\
\hline Not necessary water because is clean & \\
\hline Afraid to change water & \\
\hline Need to discuss with guardian/spouse & \\
\hline
\end{tabular}

11.8 How much can you afford to spend at one time to purchase a water treatment technology?

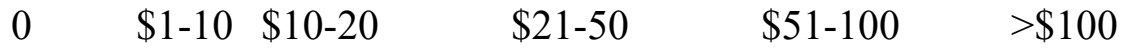

\section{Flooding}

12.1 When was the most recent flooding event?

12.2 How long did the flooding last?

12.3 Did you have issues with septic/sewer? Yes No

12.4 Did you have issues with your water quality? Yes No

13.0 Other comments or questions: 
Remember:

-remind them again that their data will not be specifically linked back to them. -photo(s) of water storage, water treatment technology, water source (tap)

-water sample

-GPS coordinates of community 
Section SI.2: Survey in Spanish

\subsection{Introducción:}

\section{Colonias: Encuesta de Línea Base a Hogares}

-Hola mi nombre es y soy un (profesor/estudiante) de en

-Tenemos permiso de ___ no estamos asociados con ninguna agencia gubernamental. Somos estudiantes aprendiendo acerca del agua en el área.

-¿Podríamos hablar con el jefe/la jefa cabeza de hogar? (si no está disponible, preguntar por un adulto mayor de 18 años)

-Estamos conduciendo una encuesta a hogares de su comunidad acerca del agua y el saneamiento básico. Quisiéramos hablar con usted/contigo por unos 15 minutos. Su/Tu participación es voluntaria: puedes negarte a contestar cualquier pregunta o terminar el cuestionario en cualquier momento si así lo deseas. Toda la información será mantenida de forma confidencial. ¿Esta claro? ¿Tienes alguna pregunta?

1.1 ¿Quisieras participar? Sí $\quad$ No $\quad$ (en caso de no, agradecer e irse del lugar)

2.0 Entrevista de antecedentes (por el encuestador):

\begin{tabular}{|l|l|c|}
\hline 2.1 & Encuesta número $(1,2,3 \ldots)$ & \\
\hline 2.2 & Nombre del encuestador & \\
\hline 2.3 & Comunidad & $/$ \\
\hline 2.4 & Fecha & $/$ \\
\hline 2.5 & Tiempo inicio - Finalización (duración) & \\
\hline 2.6 & Coordenadas GPS (N/S, E/W) de la comunidad & tráiler o base (foundation) \\
\hline 2.7 & Tipo de casa & min) \\
\hline
\end{tabular}

\subsection{Información acerca del hogar:}

3.1 Edad:

Género:

3.2 ¿Cuál ha sido el nivel educativo más alto alcanzado por cualquier habitante de esta casa?

Algo de escuela primaria

Escuela secundaria

Otro:
Escuela primaria

Algo de universidad
Algo de secundaria Grado universitario

3.3 Número de adultos (mayores de 18 años) en el hogar (incluyendo al entrevistado)

3.4 Número de ancianos (mayores de 65 años) en el hogar

3.5 Número de niños y niñas en el hogar

3.6 Edades:

3.7 ¿A qué se dedica/Cual es su ocupación?

3.8 ¿Cuantas personas pueden leer y escribir en inglés en el hogar? leer y escribir 
3.9 ¿Cuantas personas puede hablar en inglés en el hogar?

hablar

3.10 ¿Cuál es su ingreso mensual/Cuanto gana mensualmente?

Menos de \$250 $\quad \$ 250-750 \quad \$ 750-1000 \quad \$ 1000-1500 \quad$ Más de $\$ 1500$ al mes

¿Tiene__ ? (marque si tienen alguno de los siguientes)

\begin{tabular}{|l|l|l|}
\hline 3.11 & Electricidad & \\
\hline 3.12 & Horno microondas & \\
\hline 3.13 & Teléfono celular & \\
\hline 3.14 & Teléfono inteligente & \\
\hline 3.15 & Acceso a internet & \\
\hline 3.16 & Agua de grifo & \\
\hline 3.17 & Alcantarillado & \\
\hline 3.18 & Tanque séptico & \\
\hline 3.19 & Recogida de basura & \\
\hline 3.20 & Ducha & \\
\hline
\end{tabular}

3.21 ¿Usted alquila o es dueño de su casa? alquila dueño

3.22 Si es dueño de su hogar, ¿tienes una escritura? Sí No

3.23 ¿Eres dueño de la tierra? Sí No

3.24 ¿Cuántas habitaciones tiene tu casa?

3.25 ¿Cuántos baños tiene tu casa?

\subsection{Higiene}

¿Lava usted sus manos?

¿Cuando acostumbra usted a hacerlo?

\begin{tabular}{|l|l|l|l|}
\hline & & $\mathrm{Si}$ & No \\
\hline 4.1 & Después de ir al baño & & \\
\hline 4.2 & Antes de comer alimentos & & \\
\hline 4.3 & Antes de cocinar & & \\
\hline 4.4 & Otro & & \\
\hline
\end{tabular}

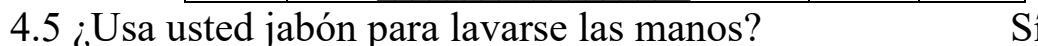

No

\subsection{Salud}

Complete las siguientes oraciones explicar verbalmente la diarrea como deposiciones blandas y acuosas (evacuaciones intestinales):

5.1 Los adultos (18-65) en el hogar sufren/padecen de diarrea

Muy frecuentemente (semanal) A menudo (mensualmente) en algunas ocasiones (varias veces al año) Muy rara vez Nunca

5.2 Ancianos ( $>65)$ en el hogar sufren/padecen de diarrea 
Muy frecuentemente (semanal) A menudo (mensualmente) en algunas ocasiones (varias veces al año) Muy rara vez Nunca

5.3 Los niños $(>18)$ en el hogar sufren/padecen de diarrea

Muy frecuentemente (semanal) A menudo (mensualmente) en algunas ocasiones (varias veces al año) Muy rara vez Nunca

5.4 ¿Cuales piensa que son las razones por las que sufren de diarrea (leer todas las opciones)?

\begin{tabular}{|l|l|}
\hline Agua sucia & \\
\hline Comida contaminada & \\
\hline Moscas/insectos & \\
\hline Malas condiciones de higiene & \\
\hline Otras & \\
\hline No está seguro & \\
\hline
\end{tabular}

5.5 ¿Trata usted sus propios síntomas de la diarrea? Sí No

5.6 Los adultos (18-65) en el hogar sufren de enfermedad respiratoria

Muy frecuentemente (semanal) A menudo (mensualmente) $\overline{\text { en algunas ocasiones }}$ (varias veces al año) Muy rara vez Nunca

5.7 Ancianos ( $>65)$ en el hogar sufren de enfermedad respiratoria

Muy frecuentemente (semanal) A menudo (mensualmente) en algunas ocasiones (varias veces al año) Muy rara vez Nunca

5.8 Los niños $(>18)$ en el hogar sufren de enfermedad respiratoria

Muy frecuentemente (semanal) A menudo (mensualmente) en algunas ocasiones (varias veces al año) Muy rara vez Nunca

5.9 ¿Cuál crees que es la principal causa de enfermedades respiratorias? (escribir respuesta)

5.10 ¿Trata usted sus propios enfermedad respiratoria? Sí No

Marque si en caso de ser cierto (dejelo en blanco en caso contrario)

\begin{tabular}{|l|l|l|}
\hline 5.11 & Tienes humidificador & \\
\hline 5.12 & Te duchas & \\
\hline 5.13 & Usa una ducha en el trabajo & \\
\hline 5.14 & Trabajar en/cerca de un edificio con una torre de enfriamiento & \\
\hline 5.15 & Fuma? & \\
\hline
\end{tabular}

\subsection{Prácticas del uso del agua:} 6.1 Fuente de recolección: 
¿De donde obtiene usted el agua de consumo (escriba C)? ¿De donde la obtiene para otras actividades? (escriba $\mathrm{O}$ )

\begin{tabular}{|l|l|l|l|}
\hline & Siempre & En ocasiones & Costo estimado por mes (\$) \\
\hline De la llave & & & \\
\hline Camión de reparto & & & \\
\hline Máquina expendedora / de llenado de agua & & & \\
\hline Agua embotellada & & & \\
\hline De un pozo & & & \\
\hline Otro: Especifique & & & \\
\hline
\end{tabular}

(Si compran agua potable que no sea del grifo (embotellada y expendedora)) 6.2 ¿Por qué compra agua potable que no sea del grifo? (marque uno)

\begin{tabular}{|l|l|l|}
\hline & $\begin{array}{l}\text { Verifique } \\
\text { si aplica }\end{array}$ & comentarios \\
\hline $\begin{array}{l}\text { Le dijeron que el agua entubada no es segura } \\
\text { (liste quién dijo en los comentarios) }\end{array}$ & & \\
\hline Usted cree que es necesario comprar agua & & \\
\hline Siempre has bebido solo agua comprada & & \\
\hline Otro: Especifique & & \\
\hline
\end{tabular}

6.3 ¿Usas agua del grifo

\begin{tabular}{|l|l|}
\hline beber & \\
\hline lavarse las manos & \\
\hline lavar los plantos & \\
\hline Lavar la ropa & \\
\hline cocinar & \\
\hline bañarse o ducharse & \\
\hline
\end{tabular}

6.4 ¿Hay algún tipo de corte del servicio en alguna temporada?

\section{Almacenamiento del agua:}

6.5 ¿Almacena usted el agua para utilizarla después? ¿En donde almacena el agua en su hogar (antes de beber, después de filtrar, al recolectar)? (Marque todas las que aplican)

\begin{tabular}{|l|l|l|l|}
\hline & Número & Tamaño aproximado (L) & Edad del contenedor (meses) \\
\hline Contenedor de cerámica & & & \\
\hline Balde metálico & & & \\
\hline Balde plástico & & & \\
\hline Bidón metálica & & & \\
\hline Recipientes pequeños & & & \\
\hline Ollas & & & \\
\hline Botellas plásticas & & & \\
\hline Otro (especifique) & & & \\
\hline
\end{tabular}

6.7 ¿Cubre usted todos sus recipientes de almacenamiento de agua?

$\mathrm{Si}$

No 
6.8 ¿Como toma el agua usted de estos recipientes?

\begin{tabular}{|l|l|}
\hline Directamente, tomo el recipiente y echo en otro recipiente & \\
\hline Con un una cuchara o un vaso con agarradera & \\
\hline Con un una cuchara o un vaso sin agarradera & \\
\hline De la llave del recipiente & \\
\hline Otro (especifique) & \\
\hline
\end{tabular}

\subsection{Perception of water quality}

Evalúa los siguientes enunciados (1-No estoy de acuerdo, 5-Estoy de acuerdo)

\begin{tabular}{|l|l|l|}
\hline$\#$ & Statement & response (1-5) \\
\hline 7.1 & Creo que la calidad del agua de grifo necesita mejorarse & \\
\hline 7.2 & Estoy satisfecho con el sabor del agua de grifo & \\
\hline 7.3 & No me preocupa el color del agua de grigo & \\
\hline 7.4 & No me preocupa el olor del agua de grifo & \\
\hline 7.5 & El agua de grifo es usualmente de buena calidad & \\
\hline
\end{tabular}

8.0 Perceived health risks current living conditions. Evalúa los siguientes enunciados (1-No estoy de acuerdo, 5-Estoy de acuerdo)

\begin{tabular}{|l|l|l|}
\hline$\#$ & Statement & response (1-5) \\
\hline 8.1 & Hay muchos riesgos asociados con el agua de grifo que llega a mi casa & \\
\hline 8.2 & El agua del grifo no es perjudicial & \\
\hline 8.3 & Creo que puedo enfermarme por tomar el agua que sale del grifo & \\
\hline 8.4 & Hay muchos químicos y preservantes en el agua de grifo que la hacen no saludable & \\
\hline 8.5 & Hay muchos riesgos asociados con la calidad de aire de mi hogar & \\
\hline 8.6 & La calidad del aire en mi hogar no es prejudicial & \\
\hline 8.7 & Creo que puedo enfermarme debido a la calidad del aire de mi casa? & \\
\hline
\end{tabular}

\subsection{Satisfaction with the dwelling environment}

Evalúa los siguientes enunciados (1-No estoy de acuerdo, 5-Estoy de acuerdo)

\begin{tabular}{|l|l|l|}
\hline$\#$ & Statement & response (1-5) \\
\hline 9.1 & En general, estaria feliz de vivir en esta área por los próximos 15 anos & \\
\hline 9.2 & Me siento seguro viviendo en esta colonia & \\
\hline 9.3 & Si tuviera la oportunidad preferiría vivir en otra área & \\
\hline 9.4 & Me sentiría seguro yéndome de esta colonia a una nueva ciudad & \\
\hline 9.5 & Estaría feliz si mi hijo se muda de esta colonia & \\
\hline 9.6 & Estoy dispuesto a vivir en esta colonia & \\
\hline
\end{tabular}

9.7 Cuántos años llevas viviendo en los EE-UU?

9.8 Cuántos años llevas viviendo en esta colonia?

9.9 A partir de la fecha, cuántos años tienes planeados vivir en esta colonia?

9.10 Crees que tus hijos vivirán mas adelante en esta colonia? Sí No

9.11 Estarías tranquilo si tu hijo(a) mayor de edad tiene que mudarse a más de 200 millas de distancia por motivos de trabajo o estudio? 


\subsection{Security of Water Quality and Quantity}

Evalúa los siguientes enunciados (1-No estoy de acuerdo, 5-Estoy de acuerdo)

\begin{tabular}{|l|l|l|}
\hline$\#$ & Statement & response (1-5) \\
\hline 10.1 & Estoy satisfecho con la cantidad de agua que proviene del grifo. & \\
\hline 10.2 & Me gustaria tener major calidad de agua en mi hogar & \\
\hline 10.3 & La calidad del agua del grifo ha emporado desde que me mudé a esta colonia & \\
\hline 10.4 & Cada vez que abro el grifo hay suficiente agua & \\
\hline 10.5 & $\begin{array}{l}\text { Tengo la suficiente cantidad de recipientes para satisfacer lo que demanda mi } \\
\text { familia }\end{array}$ & \\
\hline
\end{tabular}

\subsection{Tratamiento de agua}

11.1 ¿Utiliza algún modo para tratar el agua? Si la respuesta es sí, ¿que método utiliza y cuanto le cuesta?

Sí

11. 2 Método:

11.3 Costo de la compra:

11.4 Costo de mantenimiento:

11.5 Con qué frecuencia hace el mantenimiento? (selecciona una respuesta)

anualmente mensualmente semanalmente nunca

Preparación del hogar para usar un nuevo método de tratamiento (Si NO se cuenta con un método de tratamiento actualmente):

11.6 Estaría usted dispuesto a tratar el agua antes de consumirla? Sí No 11.7 Si la respuesta es no, ¿por qué?

\begin{tabular}{|l|l|}
\hline Costo & \\
\hline No es necesario, el agua es limpia & \\
\hline Temor de cambiar el agua & \\
\hline Necesita consultarlo con el jefe/jefa de hogar & \\
\hline
\end{tabular}

11.8 ¿Cuanto estaría usted o su hogar dispuesto a pagar por un sistema para el tratamiento del agua?

$0 \quad \$ 1-10 \quad \$ 10-20 \quad \$ 21-50 \quad \$ 51-100 \quad>\$ 100$

\section{Flooding}

12.1 ¿Cuándo fue el evento de inundación más reciente?

12.2 ¿Cuánto duró la inundación?

12.3 ¿Problemas con el sistema séptico / alcantarillado? Sí no

12.4 ¿Problemas con la calidad del agua? Sí no

13.0 Otros comentarios of preguntas: 
Recuerde: -Marque el tiempo de finalización

-Foto(s) del modo de almacenamiento de agua, la tecnología de tratamiento de agua -Muestra de agua

-Coordenadas de GPS de la comunidad 
Section SI.3: Water sampling and testing

Water samples were collected from 85 of the 114 surveyed households and were analyzed for chemical, physical, and microbiological water quality parameters across 23 colonias. The colonias in El Paso County were Montana Vista, Zaragosa, Revolucion, North and South Sparks, Fortuna, and Los Colonias. The colonias in Nueces County were Country Club, The Ranch, Cyndie Park, Railroad, Fiesta Ranch, Primavera, Petronila Estates, Tierra Grande, and Poenish Acres. The colonias in Starr County were Ray Travino (La Gloria), Los Mesquites, North Santa Cruz, La Reforma, South Santa Cruz, Share 52, and one unnamed colonia. Researchers collected the water samples themselves with gloved hands to avoid contamination. Water samples were analyzed for chemical, physical, and microbiological water quality parameters. All treated water samples (i.e., piped water) were analyzed on-site for total chlorine with a HACH DR1900 portable device. All collected samples were analyzed on-site (within 30 min of collection) for $\mathrm{pH}$, temperature, conductivity, and total dissolved solids with a Myron $\mathrm{L}$ Ultrameter III (Carlsbad, CA). For water samples that were treated+piped, sodium thiosulfate $(0.1 \mathrm{~N})$ was added at $1 \%$ by volume to the microbial samples to ensure that disinfection of bacteria did not continue over time. ${ }^{1}$ For additional water quality parameters, water samples were stored on ice in a cooler and analyzed in the laboratories of University of Texas at Austin. For Nueces and Starr Counties, samples were kept on ice, no longer than $48 \mathrm{~h}$ prior to analysis. For El Paso County, on the other hand, samples were stored for $72 \mathrm{~h}$ or less prior to analysis. During storage, fresh ice was added to maintain the temperature. The quantification of heterotrophic plate counts (HPC) and total coliforms/Escherichia coli (E. coli, a fecal indicator bacteria) were completed using HPC and Colilert, respectively, in Quanti-2000 Trays (IDEXX, Westbrook, Maine). Sterilized beakers and water were used for dilutions and dissolving reagent, and the trays were sealed for incubation following the manufacturer's procedure. Negative controls were used for the microbial analyses. Each sample was analyzed on an Agilent 710-ES Inductively Coupled Plasma Optical Emission Spectrometer (Agilent Technologies, Santa Clara, CA) for a comprehensive metal analysis and on a Thermo Scientific iCAPTM RQ Inductively Coupled Plasma Mass Spectrometer (ICP-MS) for lead. Arsenic was measured with Quick Arsenic II test kits, a United States Environmental Protection Agency (USEPA) verified method (Industrial Test Systems Inc.; Rock Hill, SC). Sample dilutions were completed according to the manufacturer's protocol; i.e., if the measured concentration was $>10 \mu \mathrm{g} / \mathrm{L}$, the sample was diluted. The Quick 
Arsenic II kit has been recently documented to be one of the most accurate and precise among similar field kits for measuring arsenic in drinking water. ${ }^{2}$ The samples from Starr County were also analyzed for arsenic by ICP-MS and compared to the Quick Arsenic II kit (Figure SI.1). The results show fairly good agreement between these two methods; measuring arsenic with the field kit has proved to be accurate in assessing if the water contained arsenic above the USEPA's maximum contaminant level (MCL). However, it is noteworthy that, overall, the Quick Arsenic II kit has a slight negative bias, so the kits may underestimate the concentration of arsenic in some cases. In all analytical techniques, NIST-certified standards were used to generate standard curves with $\mathrm{R}^{2}$ values $>0.999$. The results were compared to USEPA's primary and secondary MCLs. 
Section SI.4: Other latent variables probed related to household health, sanitation, and living in a colonia

Six questions in the survey were asked to assess household health with regard to frequency of diarrhea and respiratory sickness (Table SI.1). All of these surveyed variables have a standardized loading greater than 0.4 and are statistically significant with a p-value less than 0.05. The calculated household factor scores for household health were used in the SEM. The hypothesized SEM was originally designed to include the variable: extent of sanitation practices and waste management; however, this combined variable was transformed into presence of sanitary sewer, which was determined to be a more accurate hypothesized predictor of measured water quality and household health. The two latent variables of perceived health risk from current living conditions and satisfaction with the dwelling environment were designed to assess the essence of living in a colonia (Table SI.1). For perceived health risk from current living conditions, all of these surveyed variables have a standardized loading greater than 0.4 and are statistically significant with the exception of one variable, which was removed from the analysis. The calculated household factor scores for perceived health risk from current living conditions were used in the SEM. Eleven questions in the survey were asked to assess satisfaction with the $d$ welling environment. Seven of these surveyed variables have a standardized loading greater than 0.4 and are statistically significant. The calculated household factor scores for satisfaction with the dwelling environment were used in the SEM. 
Section SI.5: Description of structural equation modeling and code utilized in MPlus and output from modeling

SEM is a statistical tool that takes a confirmatory approach to the analysis of a structural theory based on some phenomenon. ${ }^{3}$ Causal processes within a study are represented by a series of structural (i.e., regression) equations, and the structural relations can be modeled pictorially to enable a clearer conceptualization of the proposed theory. The hypothesized model is tested statistically in a simultaneous analysis of the entire system of variables to determine the extent to which it is consistent with the data. If goodness-of-fit is met, the model argues for plausibility of the postulated relations among variables. If not, the tenability of such relations is rejected. In other words, SEM takes a confirmatory approach to the data analysis while providing explicit estimates of error variance parameters. The analysis of data can be used for inferential purposes, i.e., can be used to generalize conclusions from the sample set to a larger population (most other multivariate procedures are descriptive by nature).

Hypotheses for the structural equation model have been developed based on published data to depict relationships between latent variables, and together these relationships form the overall model. ${ }^{4-11}$ Details on the justification of these hypotheses and specific references are shown in Table SI.1.

- Hypothesis 1. Perceived water quality is negatively influenced by perceived health risks from one's current living conditions and positively influenced by safe water practices and satisfaction with the dwelling environment.

- Hypothesis 2. Perceived health risk from the current living conditions is negatively influenced by household health and satisfaction with the dwelling environment.

- Hypothesis 3. Household health is positively influenced by the extent of sanitation and waste management, safe water use practices, and socio-economic status.

- Hypothesis 4. Safe water use practices are positively influenced by education level and socio-economic status.

- Hypothesis 5. Socio-economic status is positively influenced by education level.

The following hypotheses are postulated and have not been previously used in structural equation models. 
- Hypothesis 6. Perceived water quality is positively influenced by measured water quality.

- Hypothesis 7. Household health is positively influenced by the measured water quality.

- Hypothesis 8. Measured water quality is positively influenced by the extent of sanitation practices and waste management and safe water use practices.

- Hypothesis 9. Desire to treat water is negatively influenced by perceived water quality, positively influenced by perceived health risk from current living conditions, and negatively influenced by household health.

- Hypothesis 10. Satisfaction with the dwelling environment is positively influenced by socio-economic status and security of water quality and quantity.

- Hypothesis 11. Security of water quality and quantity is positively influenced by socioeconomic status.

One of the strengths of SEM is that it can incorporate both observed and latent variables. To incorporate latent variables into the model, an analysis needs to be completed to assess if measures or questions load onto (or accurately describe the variation in) the latent variable (or factor). Confirmatory factor analysis (CFA) was utilized to assess if the surveyed measures load onto a single latent variable. For example, five questions were included in the survey to assess perceived water quality, and CFA was used to evaluate if the results from these five questions were linked to accurately capture the single latent variable of perceived water quality. CFA was used to test whether measures load onto the latent variables individually for each of the latent variables outlined in Figure 1. At least three measures or observed variables were collected for each latent variable. The software package Mplus was used with "by" statements to load observed variables. Significant loadings ( $p$-value $<0.05$ ) with a magnitude of 0.4 or greater were used to calculate individual factor scores for each latent variable. These factor scores, determined for each household, were used for the structural equation model. Factor scores were used instead of actual factors to develop a more parsimonious model and to decrease the time needed to run the model. 
MPlus code for to calculate factor loadings:

!each factor was calculated individually

title: calculating factor loadings;

data: file is data_final.dat;

variable: names are q1-q47;

missing are a11 (-99);

usevariables are q3-q5;

categorical are q3;

!a11 categorical are q3, q7-q8, q12-q17, q18-q19, q20-q24, q25$q 31, q 32-q 37, q 41-q 42, q 43-q 50$

analysis: estimator is MLR;

iterations $=3000$;

mode1:

F1 by $\mathrm{q3}-\mathrm{q} 5$;

! $F 2$ by $q 6-q 11$

! F3 by $q 12-q 17$;

! F4 by q18-q19;

! F5 by $\mathrm{q} 20-\mathrm{q} 24$;

! F6 by q25-q31;

! F7 by $\mathrm{q} 32-\mathrm{q} 41$;

! $\mathrm{F} 8$ by $\mathrm{q} 43-\mathrm{q} 47$;

OUTPUT: STDYX;

MPlus code with significant factor loadings to calculate and save factor scores:

! the following modeling was run three times (1) for a11

colonias, (2) for colonias that utilize we11/haul as primary

water source, and (3) for colonias that utilize treated+piped

water

title: significant factor loadings to calculate and save factor scores;

data: file is data_final.dat;

variable: names are q1-q50;

idvariable is q1;

missing are a11 (-99); 
usevariables are q12-q17, q20, q21, q24, q25, q26, q27, q28, q29, q31, q32-q36, q40, q41;

categorical are $q 20, q 21, q 24, q 25, q 26, q 27, q 29, q 31, q 32-q 36$, q41;

analysis: estimator is ML;

mode1:

F3 by $\mathrm{q} 12-\mathrm{q} 17$;

$\mathrm{F} 5$ by $\mathrm{q} 20, \mathrm{q} 21, \mathrm{q} 24$;

F6 by $q 25, q 26, q 27, q 28, q 29, q 31 ;$

F7 by $q 32-q 36, q 40, q 41$;

OUTPUT: STDYX;

SAVEDATA: SAVE=FSCORES;

FILE="factorscores . dat";

Mplus code to run structural model:

title: Colonias structural model;

!data file was created from previously calculated fscores

data: file is a11_data_Fq_w.dat;

variable:

names are q1,F3,F5, F6, F7, q48, q50,q51;

missing is *;

usevariables are q48, q50, F3, F5, F6, F7;

categorical are $q 48, q 50$;

mode 1:

$\mathrm{F} 5$ on $\mathrm{F} 6, \mathrm{q} 50$;

$\mathrm{F} 6$ on $\mathrm{F} 3, \mathrm{~F} 7$;

$\mathrm{F} 3$ on $\mathrm{q} 50$, q51;

$\mathrm{q} 48$ on $\mathrm{F} 6, \mathrm{~F} 5, \mathrm{~F} 3$;

q50 on $\mathrm{q} 51$;

OUTPUT: STDYX;

Mplus code to test indirect effects with bias corrected bootstrapping:

title: Colonias structural mode1;

data: file is a11_data_Fq.dat;

variable: 


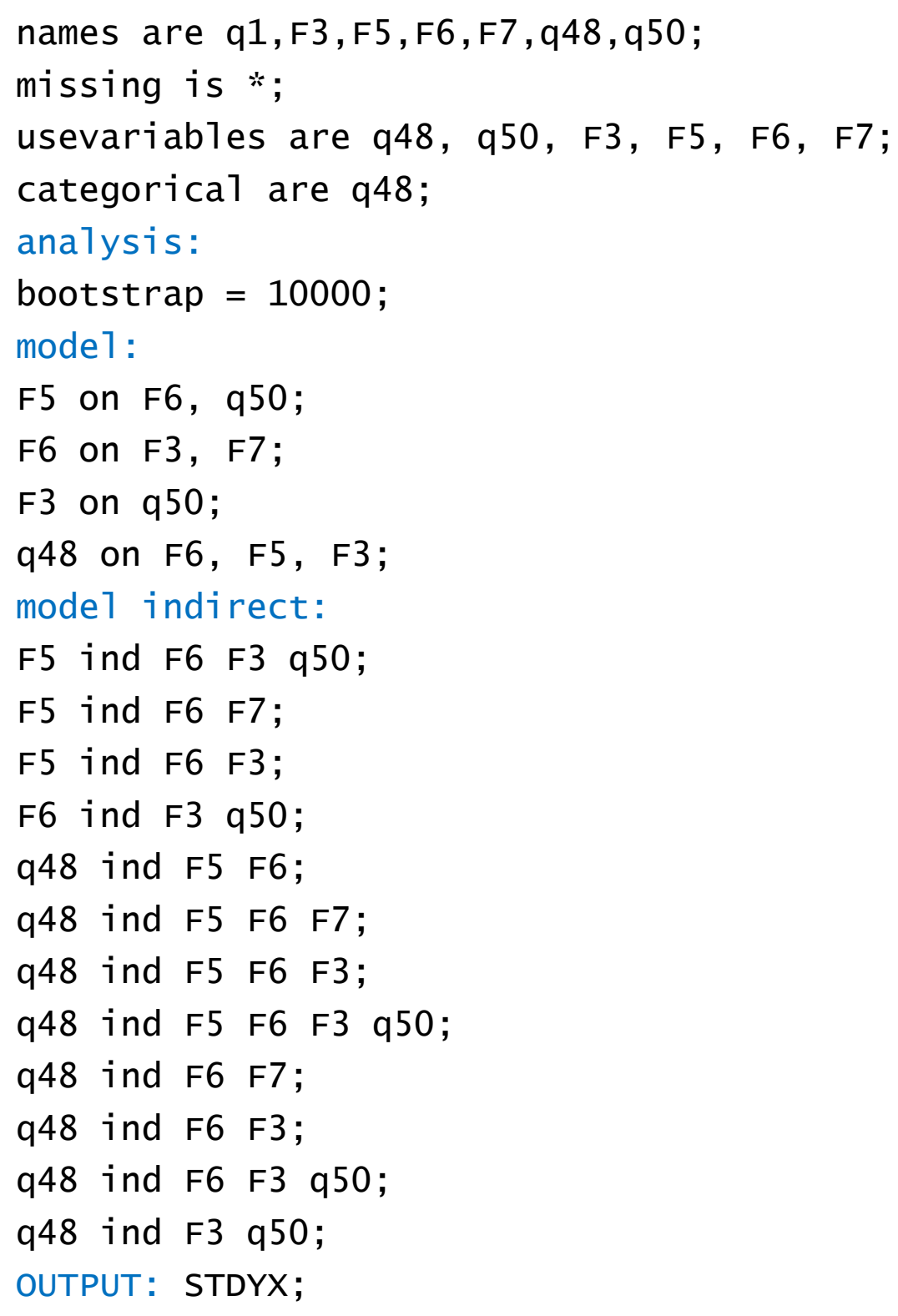




\begin{tabular}{|c|c|}
\hline Latent constructs & Observed variables with standardized loading and p-value \\
\hline $\begin{array}{l}\text { PWQ: Perceived water } \\
\text { quality } \\
\text { F5 by q20-q24 }\end{array}$ & $\begin{array}{l}\text { 7.1 PWQ1: I believe the quality of my tap water needs improvement. (reverse coded) } \\
\text { stdyx }=0.847 \text {, p-value }=0.000 \\
\text { 7.2 PWQ2: I am happy with the taste of my tap water. stdyx }=0.791, p \text {-value }=0.000 \\
\text { 7.3 PWQ3: I am happy with the color of my tap water. stdyx }=0.220, p \text {-value }=0.192 \\
\text { 7.4 PWQ4: I am happy with the odor of my tap water. stdyx }=0.359, p \text {-value }=0.025 \\
\text { 7.5 PWQ5: My tap water is usually of high quality. stdyx }=0.761, p \text {-value }=0.000\end{array}$ \\
\hline $\begin{array}{l}\text { SW: Security of water } \\
\text { quality and quantity } \\
\text { F8 q43-q47 }\end{array}$ & 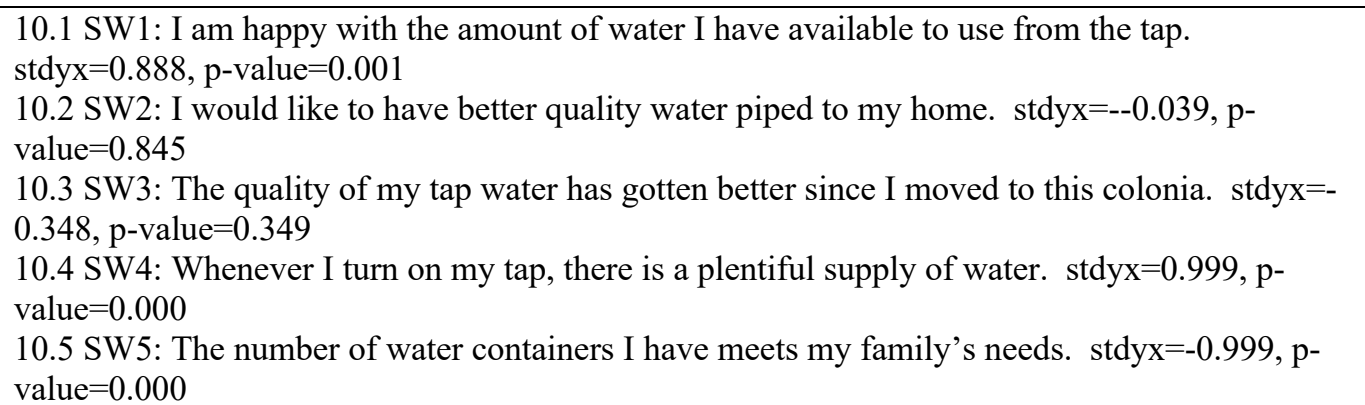 \\
\hline $\begin{array}{l}\text { PHR: Perceived health } \\
\text { risk from current } \\
\text { living conditions } \\
\text { F6 q25-q31 }\end{array}$ & $\begin{array}{l}\text { 8.1 PHR1: There are many health risks associated with drinking tap water in my home. } \\
\text { stdyx }=0.816, \mathrm{p} \text {-value }=0.000 \\
\text { 8.2 PHR2: My tap water will not harm anybody. (reverse coded) stdyx }=0.822, \mathrm{p} \text {-value }=0.000 \\
\text { 8.3 PHR3: I believe there is a possibility of becoming ill from drinking water straight from my } \\
\text { tap. stdyx }=0.897 \text {, } \mathrm{p} \text {-value }=0.000 \\
\text { 8.4 PHR4: There are so many chemicals and additives in my tap water that it must be unhealthy. } \\
\text { stdyx }=0.818, \mathrm{p} \text {-value }=0.000 \\
\text { 8.5 PHR5: There are many health risks associated with air quality in my home. stdyx }=0.465, \mathrm{p} \text { - } \\
\text { value }=0.012 \\
\text { 8.6 PHR6: The air in my home will not harm anybody. (reverse coded) stdyx }=0.245, \mathrm{p}- \\
\text { value }=0.048 \\
\text { 8.7 PHR7: } \text { I believe there is a possibility of becoming ill from the air in my home. stdyx }=0.478 \text {, } \\
\text { p-value }=0.002\end{array}$ \\
\hline $\begin{array}{l}\text { SCL: Satisfaction with } \\
\text { the dwelling } \\
\text { environment } \\
\text { F7 q32-q42 }\end{array}$ & 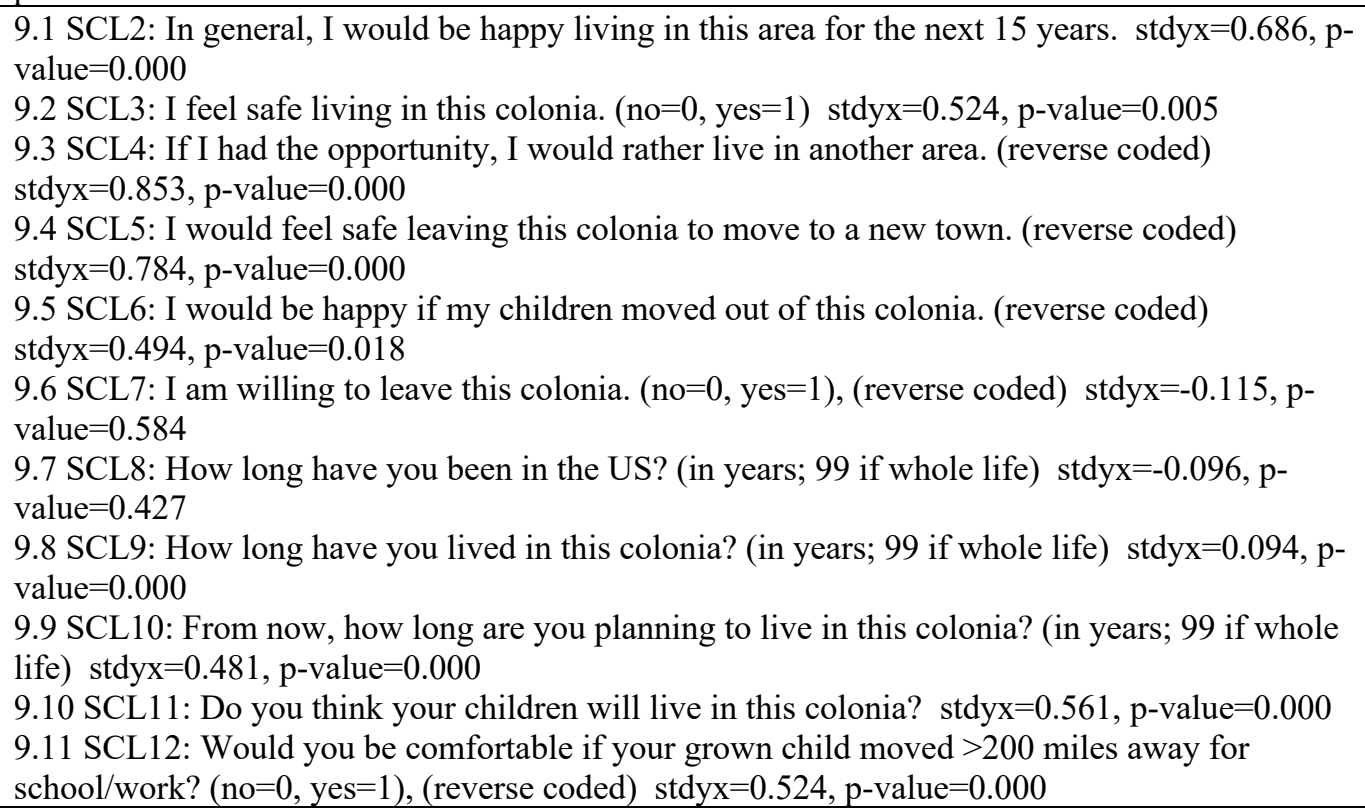 \\
\hline
\end{tabular}




\begin{tabular}{|c|c|}
\hline $\begin{array}{l}\text { EL: Education level } \\
\text { F1 by q3-q5 }\end{array}$ & $\begin{array}{l}\text { 3.2 EL1: Highest education level of person currently living in house. (coded } 1=\text { some primary to } \\
6=\text { completed university) stdyx }=0.180, p \text {-value }=0.486 \\
\text { 3.9 EL2: Number of people who can speak English. }{ }^{*} \text { Changed to percent of household } \\
\text { stdyx }=0.940, p \text {-value }=0.000 \\
\text { 3.8 EL3: Number of people who can read and write English. }{ }^{*} \text { Changed to percent of household } \\
\text { stdyx }=0.935, p \text {-value }=0.000\end{array}$ \\
\hline $\begin{array}{l}\text { SES: Socio-economic } \\
\text { status } \\
\text { F2 by q6-q11 }\end{array}$ & $\begin{array}{l}\text { 3.10 SES 1: Monthly income (coded } 1=<\$ 250 \text { to } 5=>\$ 1500) \text { stdyx }=0.075, p \text {-value }=0.416 \\
\text { 3.21 SES 2: Own home (no }=0, \text { yes }=1) \text { stdyx }=0.638, p \text {-value }=0.029 \\
\text { 3.22 SES 3: Have a deed (no }=0, \text { yes }=1) \text { stdyx }=0.736, p \text {-value }=0.000 \\
\text { 3.23 SES 4: Own land (no }=0, \text { yes }=1) \text { stdyx }=0.494, p \text {-value }=0.004 \\
\text { 3.24 SES 6: Number of bedrooms stdyx }=0.699, p \text {-value }=0.000 \\
\text { 3.25 SES 7: Number of bathrooms stdyx }=0.421, p \text {-value }=0.015\end{array}$ \\
\hline $\begin{array}{l}\text { HH: Household health } \\
\text { F3 by q12-q17 }\end{array}$ & 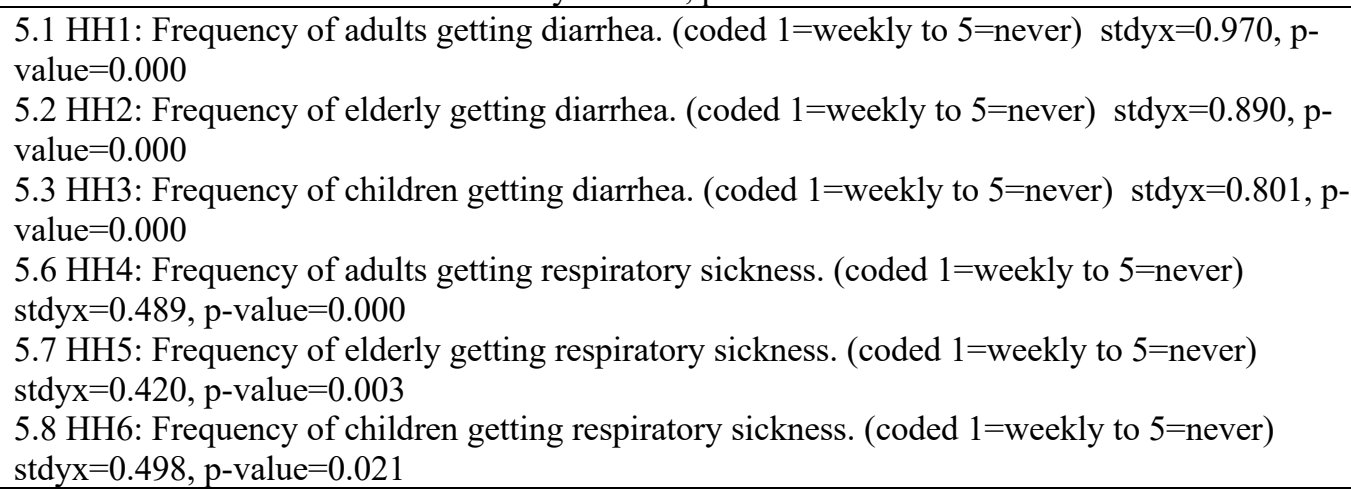 \\
\hline $\begin{array}{l}\text { SWP: Safe water use } \\
\text { practices } \\
\text { F4 by q18-q19 }\end{array}$ & $\begin{array}{l}\text { 6.7 SWP1: Cover all containers (no }=0 \text {, yes }=1) \text { stdyx }=0.009 \text {, } p \text {-value }=0.696 \\
\text { 6.8 SWP2: Remove water in safe manor from all containers (pour directly }=1 \text {, scoop with } \\
\text { handle }=2 \text {, scoop without handle }=3 \text {, spigot }=4 \text {, other }=5 ; 3 \text { and } 5 \text { classified as unsafe) } \\
\text { stdyx }=0.057, p \text {-value }=0.996\end{array}$ \\
\hline $\begin{array}{l}\text { MWQ: Measured } \\
\text { water quality }\end{array}$ & $\begin{array}{l}\text { MWQ1: Disinfectant present } \\
\text { MWQ2: Free of all harmful metals } \\
\text { MWQ3: Microbial water quality }\end{array}$ \\
\hline $\begin{array}{l}\text { PSS: Presence of } \\
\text { sanitary sewer }\end{array}$ & SWM1: Sanitary sewer system present (no= \\
\hline
\end{tabular}


(1) Huang, H. I.; Shih, H. Y.; Lee, C. M.; Yang, T. C.; Lay, J. J.; Lin, Y. E. In Vitro Efficacy of Copper and Silver Ions in Eradicating Pseudomonas Aeruginosa, Stenotrophomonas Maltophilia and Acinetobacter Baumannii: Implications for on-Site Disinfection for Hospital Infection Control. Water Res. 2008, 42, 73-80. https://doi.org/10.1016/j.watres.2007.07.003.

(2) Reddy, R. R.; Rodriguez, G. D.; Webster, T. M.; Abedin, M. J.; Karim, M. R.; Raskin, L.; Hayes, K. F. Evaluation of Arsenic Field Test Kits for Drinking Water: Recommendations for Improvement and Implications for Arsenic Affected Regions Such as Bangladesh. Water Res. 2020, 170, 115325. https://doi.org/10.1016/j.watres.2019.115325.

(3) Byrne, B. M. Structural Equation Modeling with M plus. Basic Concepts, Applications, and Programming; 2012.

(4) Divelbiss, D. W.; Boccelli, D. L.; Succop, P. A.; Oerther, D. B. Environmental Health and Household Demographics Impacting Biosand Filter Maintenance and Diarrhea in Guatemala: An Application of Structural Equation Modeling. Environ. Sci. Technol. 2013, 47 (3), 1638-1645. https://doi.org/10.1021/es303624a.

(5) Leveque, J. G.; Burns, R. C. A Structural Equation Modeling Approach to Water Quality Perceptions. J. Environ. Manage. 2017, 197, 440-447. https://doi.org/10.1016/j.jenvman.2017.04.024.

(6) Syme, G. J.; Williams, K. D. The Psychology of Drinking Water Quality: An Exploratory Study. Water Resour. Res. 1993, 29 (12), 4003-4010. https://doi.org/10.1029/93WR01933.

(7) De Franca Doria, M.; Pidgeon, N.; Hunter, P. Perception of Tap Water Risks and Quality: A Structural Equation Model Approach. Water Sci. Technol. 2005, 52 (8), 143-149.

(8) Araral, E. Improving Effectiveness and Efficiency in the Water Sector: Institutions, Infrastructure and Indicators. Water Policy 2010, 12 (SUPPL. 1), 1-7. https://doi.org/10.2166/wp.2009.051.

(9) Dutcher, D. D.; Finley, J. C.; Luloff, A. E.; Johnson, J. B. Connectivity With Nature as a Measure of Environmental Values. https://doi.org/10.1177/0013916506298794.

(10) Bollen, K. A. Structural Equations with Latent Variables; Wiley, 1989.

(11) De, M.; Doria, F.; Pidgeon, N.; Hunter, P. R.; Doria, M. de F.; Pidgeon, N.; Hunter, P. R. Perceptions of Drinking Water Quality and Risk and Its Effect on Behaviour: A CrossNational Study 认r. Sci. Total Environ. 2009, 407 (21), 5455-5464. https://doi.org/10.1016/j.scitotenv.2009.06.031. 